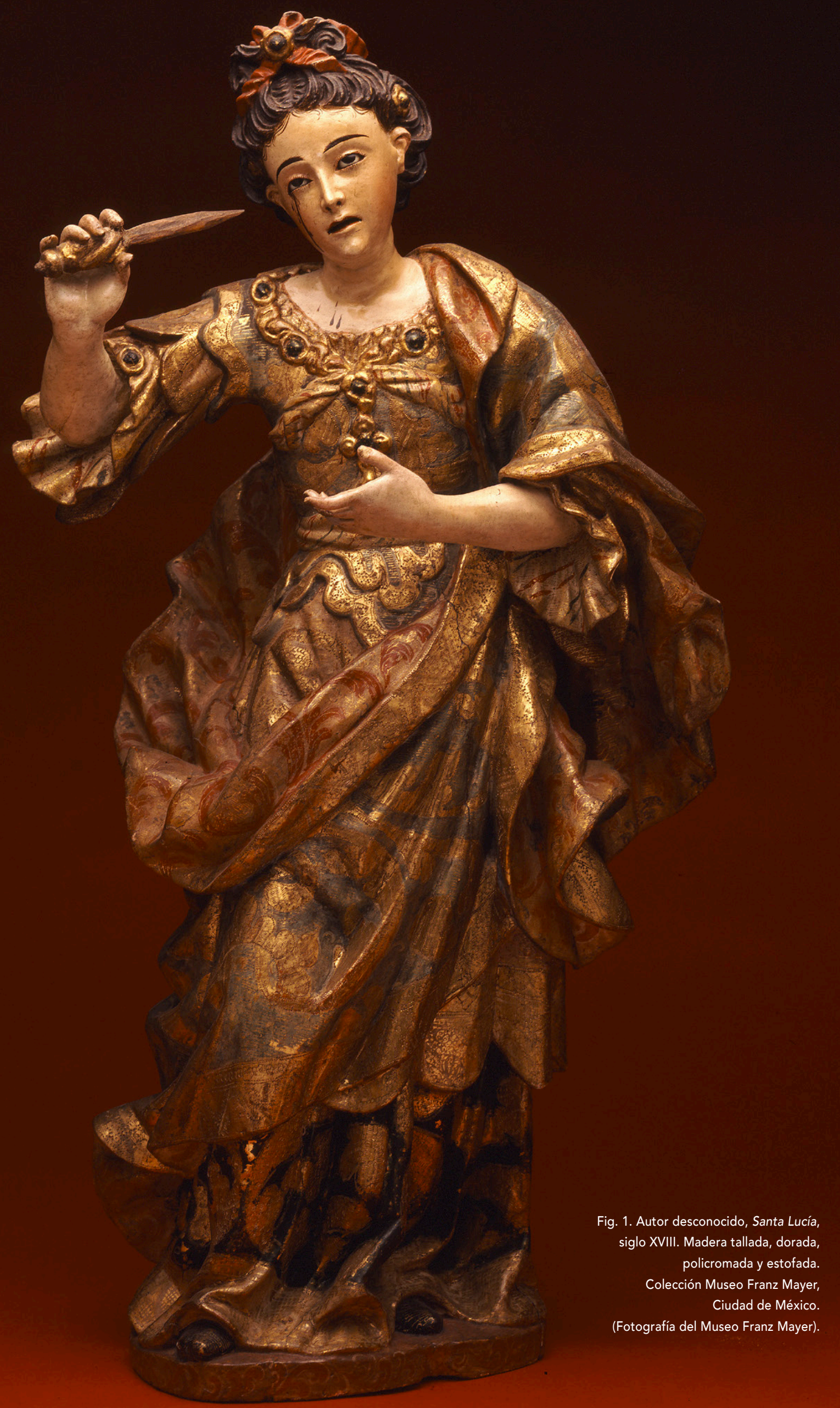




\title{
Santas mártires vestidas de oro y rica policromía. Dos esculturas novohispanas del siglo XVIII en el acervo del Museo Franz Mayer de México
}

\author{
Holy Martyrs Dressed in Gold and Rich Polychromy: Two Novohispanic Sculptures \\ from the XVIII Century in the Franz Mayer Museum Collection in Mexico
}

\author{
Montserrat A. Báez Hernández \\ Museo de Arte e Historia de Guanajuato, México \\ montse_baez@hotmail.com \\ https://orcid.org/0000-0001-5770-7048
}

\section{Resumen}

El Museo Franz Mayer de la Ciudad de México alberga en su colección un par de esculturas de santas mártires fechadas en el siglo XVIII, obras que destacan tanto por sus características formales y ornamentales, como por la singularidad iconográfica que muestra una de ellas. Dichos elementos motivaron el interés para realizar su análisis a partir de dos aproximaciones: la primera, en lo concerniente a la calidad de la policromía y la caracterización de los motivos presentes en la indumentaria de las santas, y la segunda, en lo relativo a la identificación de una de ellas como la mártir Lucía de Siracusa. El objetivo es llamar la atención a este par de tallas, ejemplos

\begin{abstract}
The Franz Mayer Museum in Mexico City is home to a pair of sculptures representing holy martyrs that date back to the 18th century. The works stand out due to their formal and ornamental characteristics, and the uniqueness of the iconography depicted in one of them. This led to the interest in studying these pieces from two different approaches: first, the quality of the polychromy and the ornamental motifs present in saint's apparel, and the second, the identification of one of them as the martyr Lucia de Siracusa. The aim of this study is to draw attention to this pair of carvings as examples of polychrome sculpture in New Spain, taking into account their iconography and the display of multiple
\end{abstract}

Cómo citar este trabajo / How to cite this paper:

Báez Hernández, Montserrat A. "Santas mártires vestidas de oro y rica policromía. Dos esculturas novohispanas del siglo XVIII en el acervo del Museo Franz Mayer de México." Atrio. Revista de Historia del Arte, no. 25 (2019): 98-119.

(C) 2019 Montserrat A. Báez Hernández. Este es un artículo de acceso abierto distribuido bajo los términos de la licencia Creative Commons Attribution-NonCommercial-ShareAlike 4.0. International License (CC BY-NC-SA 4.0). 
de la producción escultórica novohispana, tanto por la lectura que implica su iconografía, como por el despliegue de los múltiples recursos que el artífice anónimo utilizó para la correcta representación de ricos tejidos y textiles.

Palabras clave: escultura policromada; mártir; santa Lucía; Nueva España; iconografía. resources used by the anonymous sculptor in the correct representation of rich fabrics and textiles.

Keywords: polychromed sculpture; martyr; saint Lucia; New Spain; iconography.

El Museo Franz Mayer de la Ciudad de México tiene su origen en la colección formada por Franz Mayer Traumann (Mannheim, Alemania, 1882-Ciudad de México, 1975), empresario financiero alemán establecido en México desde $1905 .{ }^{1}$ Su éxito en el ámbito de las finanzas y la bolsa de valores le permitió cultivar la fotografía y el coleccionismo de arte decorativo, llegando a acumular alrededor de diez mil objetos, de los siglos XVI al XIX, entre mobiliario, cerámica, textiles, pintura, escultura, platería tanto de origen europeo como novohispano. Antes de su muerte, Franz Mayer legó a México su colección, para la cual fundó un patronato y un fideicomiso cultural administrado por el Banco de México, así como los recursos económicos necesarios para instituir un museo que la albergara. ${ }^{2}$ El 15 de julio de 1986, después de varios años de trabajos de recuperación, se inauguró el museo en el antiguo hospital de San Juan de Dios de la Ciudad de México, inmueble histórico del siglo XVII acondicionado para contar con salas de exposición permanente, salas temporales y la Biblioteca Rogerio Casas-Alatriste H., espacio designado a resguardar la vasta compilación de libros raros, incunables y antiguos que también forman parte del legado del coleccionista.

El acervo artístico que Franz Mayer inició a partir de 1919 y que continuó acrecentando a lo largo de su vida se caracteriza por la singularidad y calidad de las piezas que lo componen, lo que demuestra el interés y la sensibilidad del empresario por el estudio de las artes decorativas y la Historia de Arte mexicano, temas presentes en la biblioteca que formó a la par del mismo. Sin embargo, la gran cantidad de objetos y su diversa naturaleza hace imposible su exhibición total en la colección permanente, quedando en resguardo numerosas obras que salen de bodegas solo con motivo de muestras temporales o préstamos. Un ejemplo de ello fue la exposición temporal Los escultores novohispanos y sus obras. Colección Franz Mayer, curada en el año 2012 por la Dra. María de Consuelo Maquívar, especialista en escultura producida en la Nueva España. ${ }^{3}$ El hilo conductor de la muestra se centró en caracterizar el trabajo de los escultores, talladores, ensambladores y pintores novohispanos a partir de la variedad de los formatos, técnicas y materiales presentes en las esculturas del museo. Para la muestra fueron seleccionadas más de cincuenta obras escultóricas, pinturas y documentos, de los siglos XVII al XVIII, muchas de ellas provenientes del resguardo de colecciones. Dentro de dicho conjunto, resultaron de especial interés para quien suscribe, un par de tallas de santas mártires (Figs. 1 y 2) presentes en el guion curatorial como muestra de los dorados y las policromías logradas por los artífices novohispanos.

\footnotetext{
1. Quiero expresar mi agradecimiento a Ricardo Pérez Álvarez, Director de Colecciones, y a Tania Vargas Díaz, responsable del Departamento de Acervos Documentales del Museo Franz Mayer de México. Su apoyo fue imprescindible para la realización de este artículo.

2. María Sánchez Vega, "Museo Franz Mayer: origen, historia y actualidad de una institución cultural dedicada a las artes decorativas y el diseño," Intervención. Revista internacional de Conservación, Restauración y Museología 4, no. 8 (2013): 55.

3. La muestra permaneció del 3 de febrero de 2012 al 15 de abril del mismo año.
} 


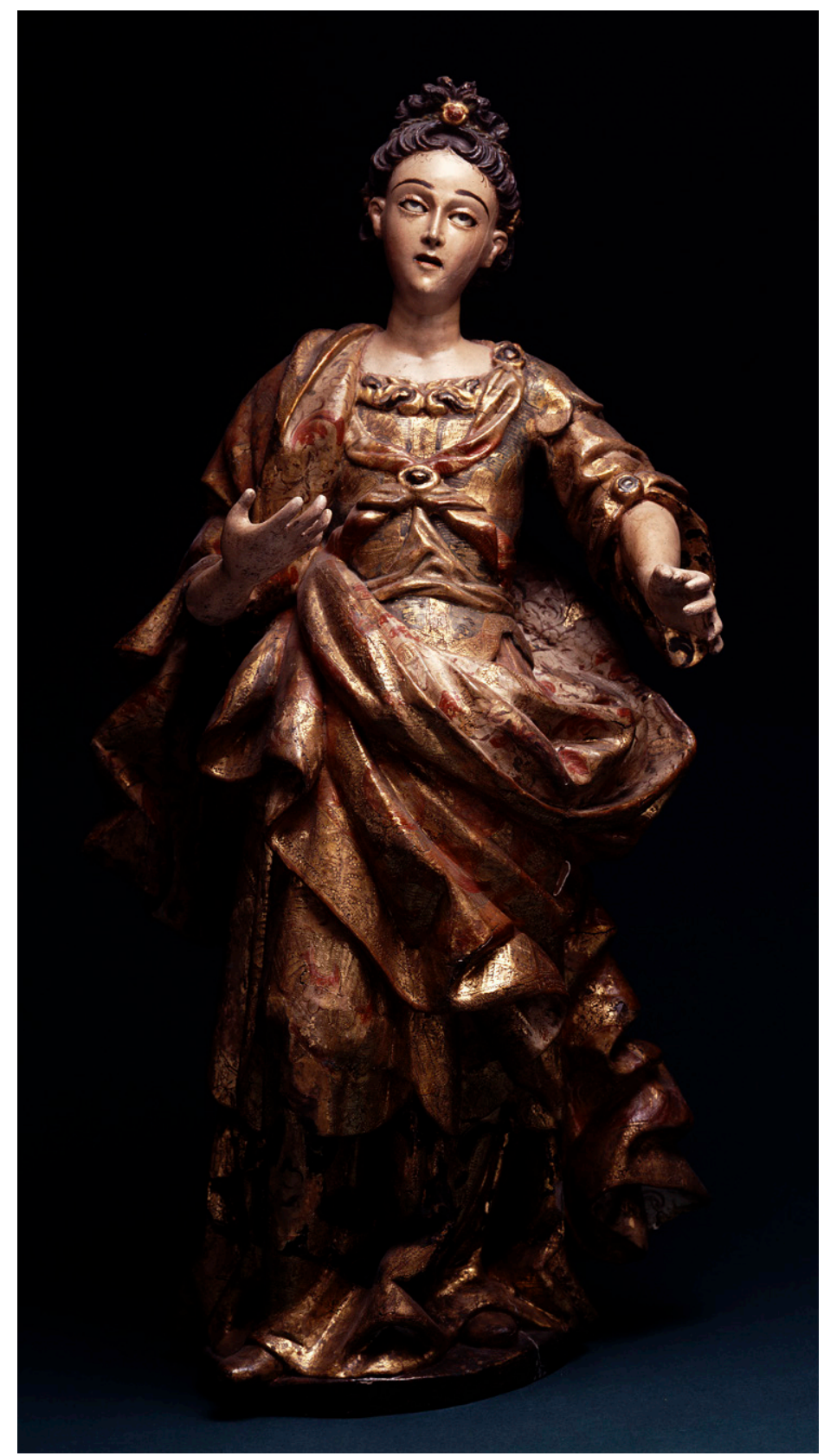

Fig. 2. Autor desconocido, Santa Lucía o santa mártir, siglo XVIII. Madera tallada, dorada, policromada y estofada. Colección Museo Franz Mayer, Ciudad de México. (Fotografía del Museo Franz Mayer).
Al respecto, un cúmulo de artículos y publicaciones recientes que problematizan sobre la necesidad de proponer nuevos marcos de referencia para el estudio de la escultura novohispana, ${ }^{4}$ plantean, además de abordarla desde sus procesos constructivos -en los que intervenían escultores, doradores y pintores-, la búsqueda de diseños característicos y señas presentes en las policromías y la representación de textiles, generalmente denominados estofados, que permitieran comenzar a caracterizar centros productores de la Nueva España como la Ciudad de México o Puebla de los Ángeles. Este creciente interés ha contribuido a afianzar la importancia de los estofados no sólo como ejemplos de la maestría y destreza de los artífices policromadores, sino también como un rasgo de identidad de la imaginería novohispana que permite identificar su presencia inclusive en regiones alejadas de América. ${ }^{5}$

Por tanto, el propósito de este artículo es contribuir al planteamiento anterior a partir de la valoración y reconocimiento del trabajo de policromía y la caracterización de los diseños presentes en las ya mencionadas esculturas de santas mártires del Museo Franz Mayer de México, buscando además, resaltar la peculiaridad presente en una de ellas como ejemplo y pervivencia de un despropósito iconográfico ya condenado desde el Concilio de Trento (1545-1563). Para el desarrollo del argumento fue necesario conjugar la revisión bibliográfica, la ins-

4. Las publicaciones se desprenden de las actividades del Seminario de Escultura Virreinal del Instituto de Investigaciones Estéticas, Universidad Nacional Autónoma de México: Pablo F. Amador Marrero y Patricia Díaz Cayeros, coord., El tejido polícromo. La escultura novohispana y su vestimenta (México: IIE-UNAM, 2013) y Pablo F. Amador Marrero et al., Ensayos de escultura virreinal en la Puebla de los Ángeles (México: Fundación Amparo, IIE-UNAM, 2012).

5. Dos ejemplos de ello son los artículos: Pablo F. Amador Marrero et al., "Las clavellinas como una de las posibles señas de identidad de los policromadores de la ciudad de México durante el siglo XVIII," en Amador Marrero y Díaz Cayeros, El tejido polícromo, 35-50; y Pablo F. Amador Marrero, "Fatto in Indie Chita delli Angeli, Puebla, México. Una imagen de San José con el Divino Infante atribuido a los Cora como parte del legado artístico de Santiago Durante a la parroquia de Toirano, Savona," Atrio. Revista de Historia del Arte, no. 23 (2017): 74-93. 
pección física de las obras y la búsqueda de fuentes visuales y escritas para el desarrollo iconográfico de las santas. El punto de partida fueron las fichas catalográficas de control de obra del museo, pues siendo las herramientas de registro de la institución que las resguarda, permitieron conocer de primera mano los datos generales de cada escultura, así como los comentarios realizados por los especialistas involucrados en su catalogación. ${ }^{6}$ Por otro lado, aunque las obras no se encuentran en la exposición permanente, sí han sido sujetas de varias menciones en publicaciones impresas, por lo que resultó imperativa la revisión de dichos artículos para conocer las aproximaciones a partir de las cuales se han estudiado. De igual forma, el trabajo directo con una de las tallas fue imprescindible para la identificación de los rasgos relativos a su sistema constructivo, los motivos ornamentales de los estofados y policromías, así como las particularidades iconográficas de su representación.

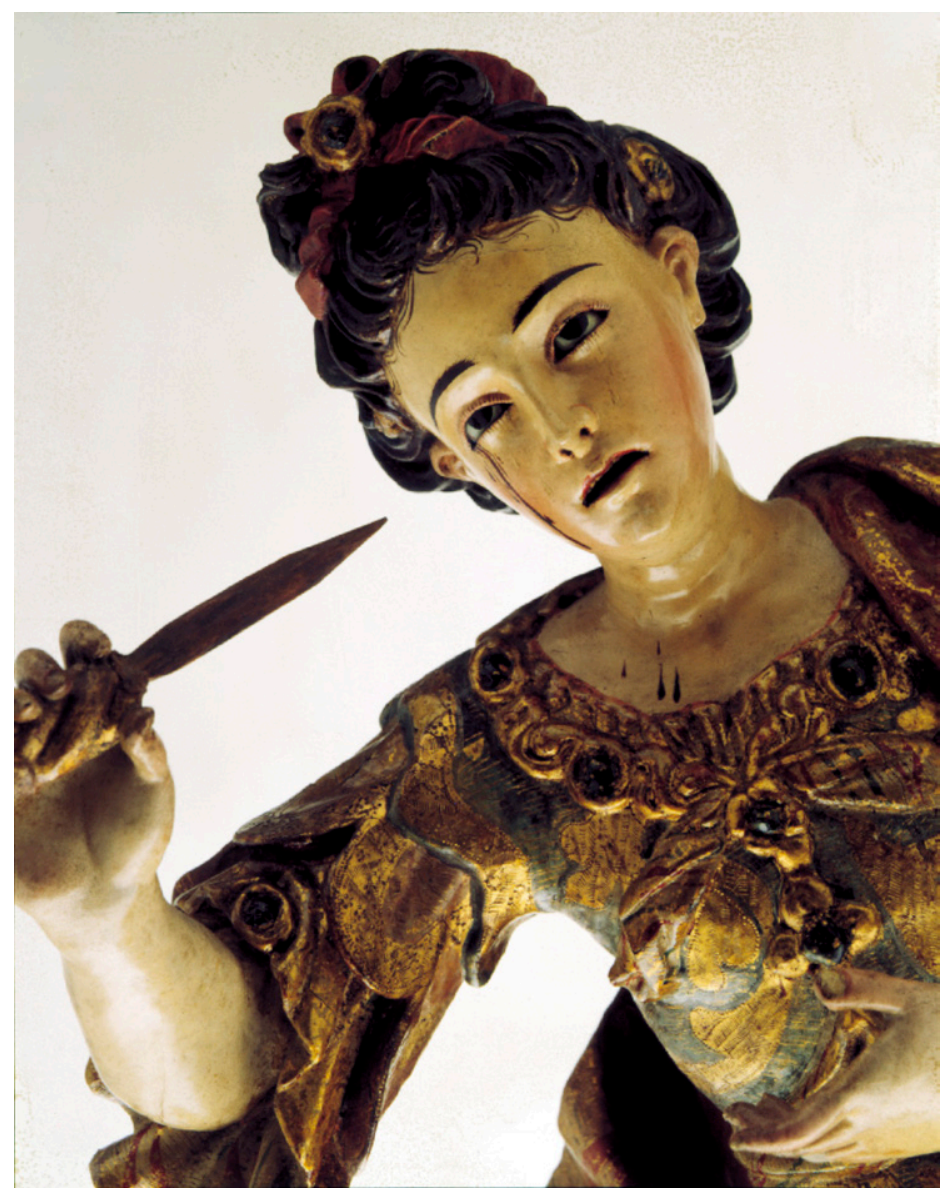

Fig. 3. Autor desconocido, Santa Lucía (detalle), siglo XVIII. Madera tallada, dorada, policromada y estofada. Colección Museo Franz Mayer, Ciudad de México. (Fotografía de Museo Franz Mayer).

\section{Las esculturas en el acervo del Museo Franz Mayer. Registro y menciones} Las fichas catalográficas de control de colecciones del Museo Franz Mayer se dividen en varios campos, siendo de utilidad para los objetivos de este artículo los relativos a "números de identificación", "datos actualizados", "comentarios" y "medidas de la obra". En el primero se observó que cada talla cuenta con cifra de procedencia, inventario y catálogo; gracias a la primera fue posible inferir que ambas fueron compradas por Franz Mayer, lo que las convierte, a diferencia de otros ejemplares que se han integrado poco a poco al acervo, en parte de la cuidadosa selección de piezas que el coleccionista adquirió a lo largo de su vida. ${ }^{7}$ Una revisión exhaustiva en el Departamento de Acervos Documentales queda pendiente para ubicar información específica que aporte mayores datos sobre la adquisición. El siguiente apartado denominado "datos actualizados" integra la información relativa al tipo de objeto, técnica, materiales, procedencia, época, etc., datos que permitieron reconocer las generalidades de las piezas; por ejemplo, llama la atención que ambas aparecen intituladas en las fichas como "Santa Lucía". A continuación, en el campo de "comentarios" aparece

\footnotetext{
6. Agradezco a la Mtra. Mayela Flores Enríquez, entonces miembro del Departamento de Investigación del Museo Franz Mayer, por todo el apoyo otorgado en 2016 para el desarrollo de lo que resultó una primera versión de este artículo, así como el permitirme examinar ambas piezas.

7. En comunicación personal con la Mtra. Mayela Flores Enríquez.
} 
la descripción formal y observaciones que fueron retomadas para los siguientes apartados de este texto. Por último, "medidas de la obra" registra las dimensiones de cada talla: 72 x $38.5 \mathrm{~cm}$ para la santa que lleva una daga en la mano, y 73 × $33 \mathrm{~cm}$ para la segunda.

En cuanto a las publicaciones sobre la colección del Museo Franz Mayer, la primera mención de las esculturas se debe a Elisa Vargaslugo, quien en el apartado "Escultura" del libro Franz Mayer. Una colección (1984), consignó que una de ellas se trata de "una preciosa figura — obra del siglo XVIII— de Santa Lucía en el momento de sacarse los ojos" (Fig. 3). ${ }^{8}$ Sin embargo, las referencias más específicas se deben a la autoría de Consuelo Maquívar en artículos dedicados al acervo escultórico del museo: en "Estofados novohispanos del Museo Franz Mayer" (1988), del Boletín no. 25 de la institución, describió al par de esculturas como "notables por la calidad de sus estofados", 9 y en la edición especial de Artes de México, Corpus Aureum. Escultura religiosa (1995), destacó el trabajo de la talla, la policromía y los estofados. ${ }^{10}$ Finalmente, en el libro Museo Franz Mayer. 20 años de arte y cultura en México (2006), las identificó como santa Lucía y santa Águeda, y afirmó que "por su expresividad y movimiento reflejan la maestría del artista que las elaboró". ${ }^{11}$ Mención extra merece santa Lucía, publicada como pieza del siglo XVIII en Imaginería virreinal: memorias de un seminario (1990), en la sección de ilustraciones, sin que esté directamente referida en los textos. ${ }^{12}$

Sentado el precedente por Elisa Vargaslugo, Consuelo Maquívar destaca al describir a las esculturas de las santas mártires como trabajos notables, ${ }^{13}$ con cuerpos bien proporcionados y movimiento por el desplazamiento natural de los brazos y los paños de la vestimenta. ${ }^{14}$ Acerca de los estofados distinguió las huellas de diferentes tipos de punzones que forman las texturas de las túnicas y mantos, ${ }^{15}$ lo que a su juicio, revelaba la calidad que alcanzaron los artistas novohispanos. ${ }^{16}$

Las esculturas son de talla en madera y están formadas por piezas que son perceptibles especialmente en las uniones de los paños y los brazos; también en la base de santa Lucía se pudieron observar agregados correspondientes al área del manto. Asimismo, la ficha catalográfica consigna que ambas cuentan con al menos seis diferentes piezas, por ejemplo los brazos, los cuales seguramente fueron tallados por separado y después agregados a la talla principal. Esta forma de construcción corresponde al embón de un solo bloque, en el que se agregaba a un núcleo los elementos necesarios para extender sus dimensiones. ${ }^{17}$ La figura de las santas es estilizada y en el caso de Lucía, con una ligera inclinación del torso hacia el frente; ambas tienen los dos pies separados, con uno levemente adelantado. La expresión de las tallas se centró en el tratamiento de los rostros, los cuales muestran gestos ambiguos con los ojos entornados y los labios entreabiertos, y también en la posición de los brazos, que fueron planificados por el artífice para sostener la daga, o los atributos hoy perdidos de la otra mártir. Para dar mayor realce, las tallas fueron detalladas con aplicación de dientes y ojos de vidrio; los cabellos, los ornamentos del los peinados, las cejas, las gotas de sangre en Lucía y las peanas, están pintadas en tonalidades que van del marrón al rojo. El rasgo más sobresaliente en definitiva es la ves-

8. Elisa Vargaslugo, "Escultura," en Franz Mayer. Una colección (México: Bancrecer, 1984), 125.

9. María del Consuelo Maquívar, "Estofados novohispanos del Museo Franz Mayer," Boletín bimestral, no. 25 mayo-junio (1988): 3.

10. María del Consuelo Maquívar, Corpus aureum. Escultura religiosa. Colección uso y estilo, Museo Franz Mayer (México: Artes de México, 1995), 53.

11. María del Consuelo Maquívar, "Escultura," en Museo Franz Mayer. 20 años de arte y cultura en México (México: Banco de México, 2006$), 272$.

12. Gustavo Curiel, coord., Imaginería virreinal: memorias de un seminario (México: IIE- UNAM, INAH, 1990), 145.

13. Maquívar, Corpus aureum, 53.

14. Maquívar, "Escultura," 272

15. Maquívar, Corpus aureum, 53.

16. Maquívar, "Escultura," 272

17. Maquívar, "Escultura," 250 
timenta de las santas, la cual está trabajada con estofados de rico colorido y textura. Por último los rostros, cuellos y brazos, muestran encarnaciones brillantes o pulidas, ${ }^{18}$ con toques de color rosáceo en las mejillas y en los labios. Debido a sus similitudes y dimensiones, es posible que hayan formado parte de un conjunto escultórico o un retablo. ${ }^{19}$

\section{Vestidas de oro y ricos textiles, las policromías presentes en la indumentaria} La obra escultórica novohispana se caracteriza por un significativo e importante deseo de representar a los personajes esculpidos de tal forma que su presencia sea más palpable y convincente para el fiel. ${ }^{20}$ En el caso de las santas mártires, la rica ornamentación para dar realce y movimiento a los pliegues de los paños resalta no solo como elemento ornamental, sino también como un medio para lograr verosimilitud, pues aunque fueron ataviadas con prendas iguales, su ornamentación y colorido está individualizado, lo que permitió al artífice policromador hacer un gran despliegue de recursos, como se verá a continuación.

Los mártires de los primeros siglos del cristianismo, antes del Concilio de Trento (1545-1563), eran personificados con mantos sencillos o bien según el gusto de la región de los artífices, los cuales solían tomarse libertades con respecto a los paisajes, las estancias y las vestimentas, siendo muchas veces pintados portando ropajes civiles elaborados con lujosos textiles y joyería. Sin embargo, el decreto "De la invocación, veneración y reliquias de los santos y de las sagradas imágenes” incluido en la sesión XXV del Concilio de Trento advertía que "no se pinten ni adornen las imágenes con hermosura escandalosa", ${ }^{21}$ condenando los excesos generados por las inexactitudes antes mencionadas. En la misma tónica, el cardenal italiano y arzobispo de Milán Carlos Borromeo (1538-1584), uno de los promotores de la última sesión del Concilio de Trento, refirió como eco en sus Instrucciones de la fábrica y del ajuar eclesiástico (1577) las normas de decoro para la construcción y disposición de las imágenes, los recintos sagrados y objetos litúrgicos. Así, en el apartado XVII, "De las sacras imágenes o pinturas" hizo énfasis en que las imágenes de los santos deben buscar que se "armonice apta y decorosamente en el hábito del cuerpo, en el estado y en el ornato, con la dignidad y santidad del prototipo". ${ }^{22}$

En consecuencia, tras el concilio, surgieron varias publicaciones enfocadas a promover la coherencia en la representación de las sagradas imágenes: De picturis et imaginibus sacris o De Historia sacrarum imaginum et picturarum (1570) de Joannes Molano; Discorso intorno alle immagini sacre e profane (1582) de Gabriele Paleotti; Diálogo de la pintura y su defensa de Vicente Carducho (1633); El Arte de la Pintura, su antigüedad y grandeza (1649) de Francisco Pacheco y El pintor christiano y erudito (1730) de Juan Interián de Ayala, entre otros, siendo estos últimos de gran relevancia para el ejercicio artístico en la Nueva España. ${ }^{23}$ Véase por ejemplo, que Interián de Ayala aconsejaba que los artífices "han de leer también a los poetas, deben

\footnotetext{
18. Maquívar, "Escultura," 54.

19. Maquívar, Corpus aureum, 53.

20. Luis Amaro Cavada et al., "Los diseños polícromos de la indumentaria de las siete esculturas principales en Santa Prisca," en Amador Marrero y Díaz Cayeros, El tejido polícromo, 79 .

21. El Sacrosanto y Ecuménico Concilio de Trento traducido al idioma castellano por Don Ignacio López de Ayala. Agrégase el texto latino corregido según la edición auténtica de Roma, publicada en 1564. Tercera edición (Madrid: Imprenta real, 1787), 359.

22. Carlos Borromeo, Instrucciones de la fábrica y del ajuar eclesiástico (México: UNAM, 2010), 39.

23. Montserrat A. Báez Hernández, "Del cuerpo violentado al cuerpo glorificado. La imagen del mártir como exemplum maius," en Gisela von Wobeser, Carolina Aguilar García, y Jorge Luis Merlo Solorio, coords., Las funciones de la imagen en el catolicismo novohispano (México: IIH-UNAM, Fideicomiso Felipe Teixidor y Monserrat Alfau de Teixidor, 2018), 195.
} 
tener conocimientos de historia, y han de leer y revolver todos los escritores de buenas artes" ${ }^{24}$ con el objetivo de estar bien instruidos en las historias y costumbres de otras naciones, los ritos de las religiones, etc., para evitar errores anacrónicos, y en el caso de las vestimentas "el atribuir a los santos sin ninguna distinción los mismos adornos y vestidos". ${ }^{25}$ Por ello, los mártires de los primeros siglos del cristianismo, bajo esta nueva búsqueda de veracidad y tomando como base el hecho de haber perecido durante las persecuciones del Imperio romano, se les representó con indumentaria de la época aunque de forma muy idealizada y con gran lujo. Así, las mujeres fueron ataviadas genéricamente como matronas romanas y los hombres como milites Christi, soldados de las huestes de Cristo. ${ }^{26}$ Este es el tipo iconográfico del pretendido mártir antiguo o "historicista" que se trasplantó a la Nueva Espańa, promovido también por la difusión de grabados flamencos de las familias Wierix, Galle, Collaert, Bolswert y más, que sirvieron como inspiración de numerosas obras salidas de los pinceles y gubias novohispanas. ${ }^{27}$

De este modo, la vestimenta que portan las esculturas de santa Lucía y la santa mártir podrían corresponder al tipo iconográfico del mártir de los primeros siglos del cristianismo. Las fichas catalográficas de ambas piezas describen que están vestidas con faldas largas cubiertas por una menor, olanes, pecheras con guarniciones doradas, mangas largas, un manto que las cubre y zapatos negros. En cuanto al peinado, llevan el cabello rizado y sujeto sobre la coronilla con cintas. ${ }^{28}$ La particularidad que presentan es la especie de pechera o corsé que remite a la loriga romana del atuendo de los mártires masculinos como milites Christi, la cual es claramente identificable en la estampa Miles Christianus (1619 aprox.) de Hieronimus Wierix, y nombrada como lorica iustitiae (coraza de la justicia), adjetivo tomado del texto bíblico Efesios, 6. En la búsqueda de referencias visuales sobre la prenda en personajes femeninos, es destacable que parece no haber sido un elemento común en la iconografía de las mártires, aunque sí fue posible ubicarla asociada a imágenes de mujeres fuertes, como en la obra Icones Illustrium Feminarum Veteris Testamenti (1590-1595), una serie de estampas dedicadas a personajes femeninos de la Biblia publicada por Philips Galle después de Maarten de Vos, en la que específicamente la portan Thamar (no. 06), Sara (no. 16), Judith (no. 17) y Esther (no. 18). La loriga presente en las mujeres de la historia del cristianismo que destacaron por su fuerza, sabiduría y virtud parece estar emparentada con la alegoría de la Fortaleza de Cesare Ripa, que aparece como "una mujer armada con coraza, yelmo, espada y lanza”. ${ }^{29}$ Otro ejemplo es el emblema Fortitudo de la Idea Vitae Teresianae (1686) en el que santa Teresa de Jesús también está ataviada con dichos atributos: la loriga, el yelmo, el escudo y la lanza.

Por tanto, es posible que las esculturas de las santas mártires porten una loriga en versión femenina a la manera de los milites Christi y también como un elemento asociado a la fortaleza, virtud que en definitiva debieron poseer los mártires al haber ofrendado su vida en nombre de Cristo. Otra interpre-

\footnotetext{
24. Juan Interián de Ayala, El pintor christiano, y erudito, ó tratado de los errores que suelen cometerse freqüentemente en pintar, y esculpir las Imágenes Sagradas. Dividido en ocho libros con un apendice. Obra útil para los que se dedican al estudio de la Sagrada Escritura, y de la Historia Eclesiástica, escrita en Latín por el M. R. P. M. Fr. Juan Interian de Ayala, de la Sagrada Real, y Militar Orden de nuestra Señora de las Mercedes, Redencion de Cautivos, Doctor Theólogo de la Universidad de Salamanca, catedrático Jubilado de Theología, Maestro de Sagradas Lenguas en dicha Universidad, y Predicador de S.M. y traducida en castellano por D. Luis de Durán y de Bastéro, presbítero, Doctor en Theología, y en ambos Derechos, del Gremio, y Claustro de la Pontificia, y Real Universidad de Cervera, Examinador Sinodal del Obispado de Urgél, y Académico de la Real Academia de Cánones, Liturgia, Historia, y Disciplina Eclesiástica de esta Corte. Tomo Segundo (Madrid: por D. Joachin Ibarra, Impresor de Cámara de S.M., 1782), 58.

25. Interián de Ayala, 58.

26. Louis Réau, Iconografía de los santos G-O, t. 2, vol. 4 (Barcelona: Ediciones del Serbal, 2000), 496.

27. Al respecto, véase Báez Hernández, "Del cuerpo violentado al cuerpo glorificado," 204-6.

28. Fichas catalográficas: Santa Lucía y santa Lucía. Museo Franz Mayer. Fecha de consulta, enero de 2019.

29. Cesare Ripa, Iconologia overo descrittione di diverse imagini cavate dall'antichità, \& di propia inventione, trovate \& dichiarate da Cesare Ripa Perugino Cavaliere de Santi Mauritio \& Lazaro. Di nuovo revista \& del medesimo ampliata di 400 \& più imagini. Et di figure d' intaglio adornata. Opera non meno utile che necessaria a Poeti, Pittori, Scultori, \& altri, per rappresentare le Virtù, Vitij, Affetti, \& Passioni humane (Roma: apresso Lepido Faeij, 1603$), 168$.
} 
tación de la prenda cuando lleva bordes o mangas lobuladas propone que se trata de un diseño utilizado por los escultores para hacer alusión a un personaje de un pasado remoto o antiguo, como es el caso de los mártires de los primeros siglos del cristianismo. ${ }^{30} \mathrm{Si}$ bien esta iconografía no parece haber sido común para la Nueva España, existen ejemplos de representaciones tanto pictóricas como escultóricas de santas mártires con la misma prenda ricamente ornamentada sobre largas faldas, con mangas abiertas y guarniciones: una talla de Santa Bárbara en uno de los retablos laterales del templo de San Juan Bautista Coixtlahuaca, Oaxaca; un lienzo anónimo de Santa Lucía en el templo de San Francisco Tehuacán, Puebla; y un óleo de Santa Bárbara, ca. 1742, firmado por José Gabriel de Ovalle en la catedral de Durango, México, por mencionar algunos ejemplos. Curiosamente esta forma de representar la vestimenta de las santas mártires parece más cercana a los modelos escultóricos portugueses y brasileños del siglo XVIII, de los que existe un gran número de ejemplos. ${ }^{31}$ Un último elemento a resaltar es el peculiar peinado de cabello recogido en un mońo en la parte superior

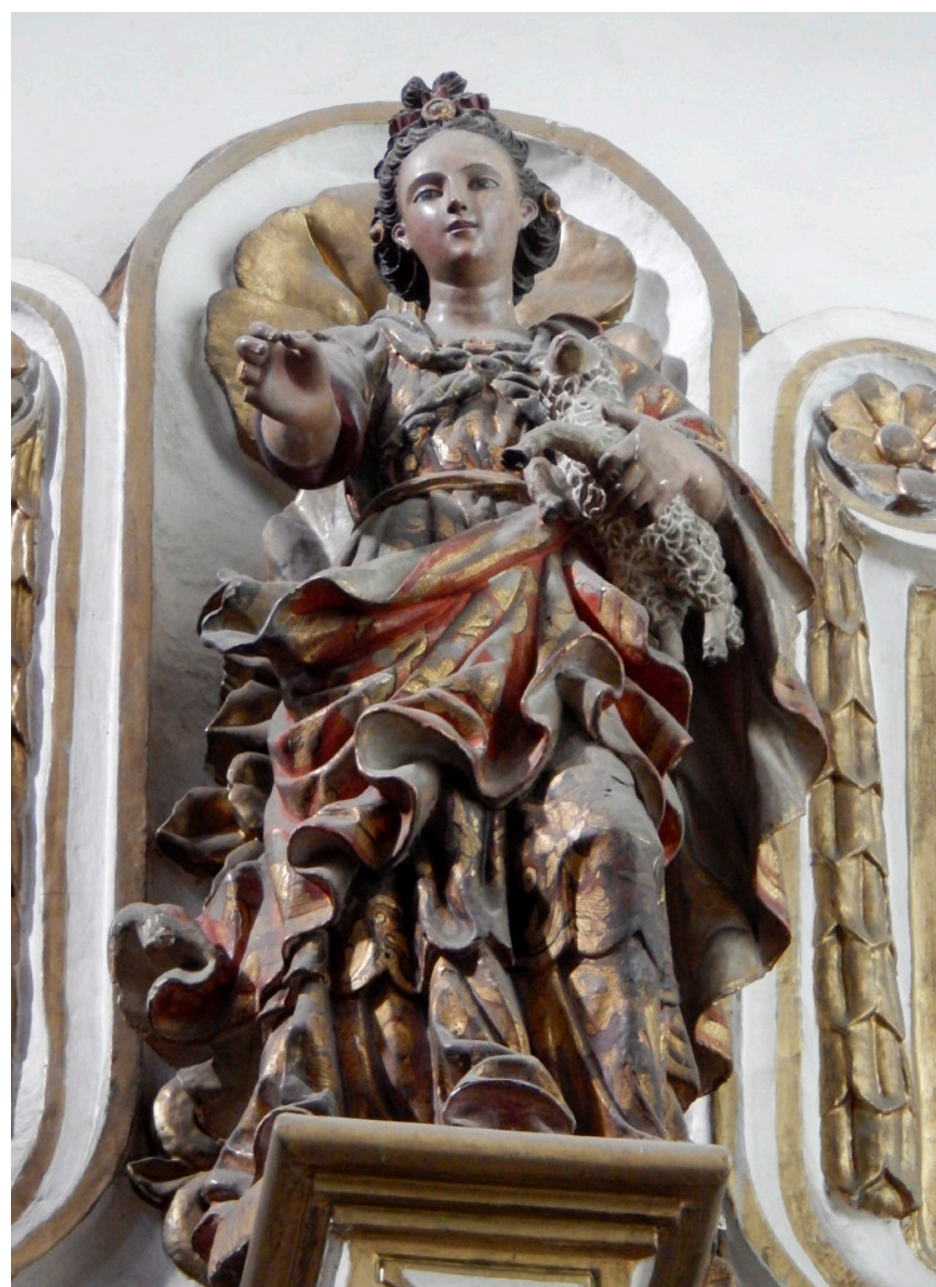

Fig. 4. Autor desconocido, Santa Inés, siglo XVIII. Madera tallada, dorada, policromada y estofada. Iglesia de San Diego de Alcalá, Aguascalientes. (Fotografía de Montserrat A. Báez Hernández). de la cabeza presente en las tallas. Este tocado aparece en obras italianas a partir del siglo XVI, como es el caso de los lienzos de Santa Lucía (1521) de Domenico Beccafumi (1486-1551) y Santa Lucía (1540) de Giovanni Filippo Criscuolo (1500-1584); y sucesivamente en siglos posteriores. Al respecto, existen testimonios escultóricos de la antigüedad clásica como la Cabeza femenina de la tumba 94 en Amphipolis Grecia, del siglo IV d. C. que lleva los cabellos sujetos hacia arriba y arreglados en un moño en la parte superior, o la Cabeza femenina del Museo Nacional Romano Termas de Diocleciano, Roma, Italia, que igualmente lleva el cabello anudado en la coronilla. Una publicación, aunque ya de siglo XIX que versa sobre peinado teatral, incluye una lámina que detalla el mismo peinado y explica que se trata de una "acabada idea de otro peinado griego, bastante caprichoso, copia de su

30. Amaro Cavada et al., "Los diseños polícromos," 80.

31. Santa Catalina de Alejandría y Santa Cecilia en la iglesia de San Francisco de Guimarães, Portugal; Santa Quiteria, talla portuguesa en el Museu da Inconfidência, Ouro Preto, Brasil; Santa Quiteria en el Museu de Arte da Bahia, Brasil; y Santa Lucía en la iglesia de San Gonzalo García, San Juan del Rei, Minas Gerais, Brasil, por mencionar algunas. 


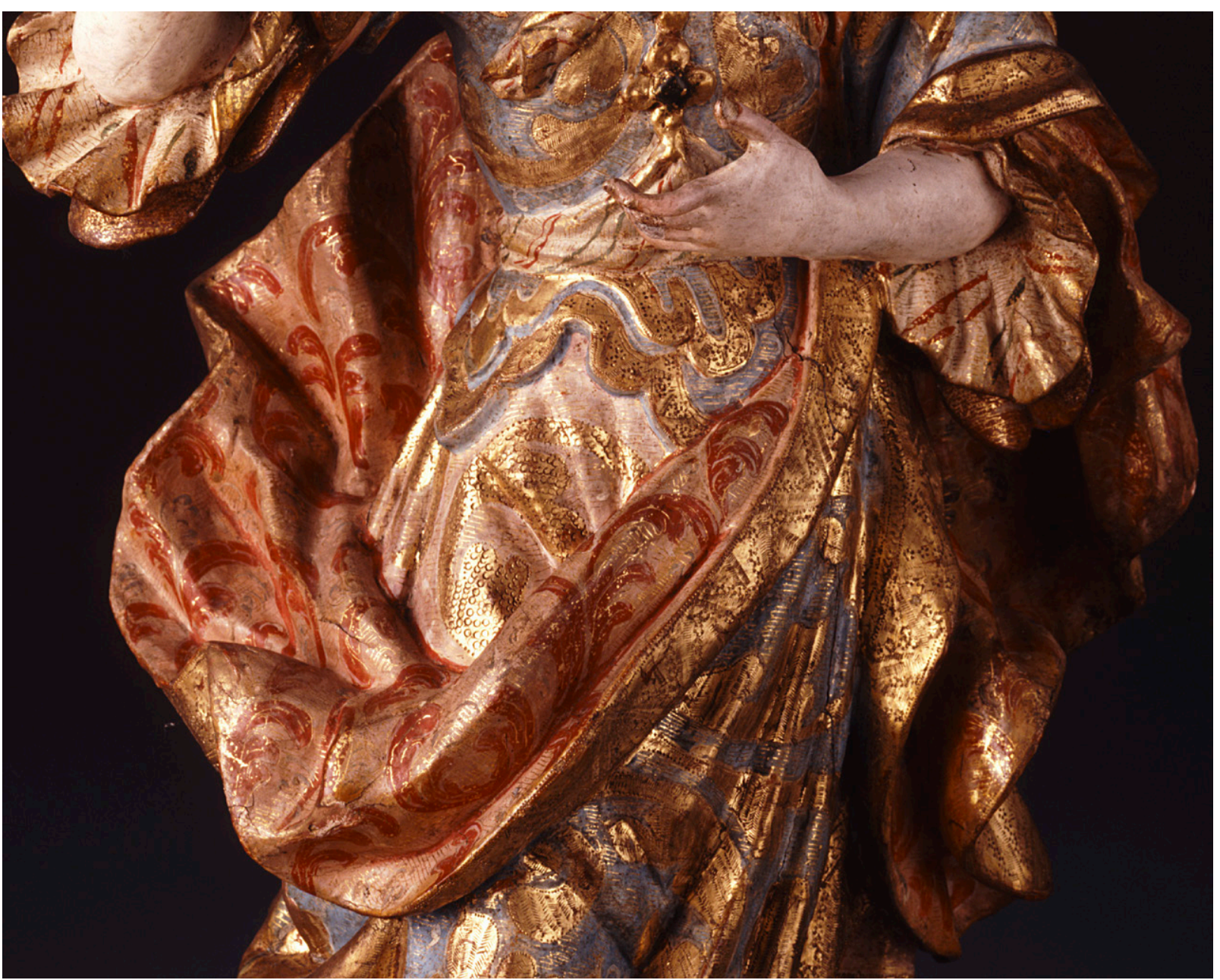

Fig. 5. Autor desconocido, Santa Lucía (detalle de la policromía), siglo XVIII. Madera tallada, dorada, policromada y estofada. Colección Museo Franz Mayer, Ciudad de México. (Fotografía del Museo Franz Mayer).

original en mármol que existe en el Museo provincial de Antigüedades de Tarragona” ${ }^{32}$ ¿Se trata este peinado de un elemento más de la interpretación historicista de los mártires de los primeros siglos?

Para cerrar con estos preliminares, es necesario apuntar que una de las fichas menciona una escultura de santa Catalina en el Landesmuseum de Stuttgart, Alemania, con la que guarda semejanzas formales y ornamentales; nota a la que añado el hallazgo de una escultura en la iglesia de San Diego de Alcalá, Aguascalientes, México (Fig. 4), en la que, sobre el marco de una puerta del lado de la epístola, se ubicó una escultura de Santa Inés que comparte numerosos rasgos con las esculturas del Museo Franz Mayer: presenta el mismo tipo de vestimenta conformada por una falda larga a la que se le superpone una corta, y aunque no porta la pechera o loriga, sí lleva el ornamento textil cruzado sobre el pecho y adornado con guarniciones, así como el manto que cuelga sobre su hombro. También ostenta el mismo peinado recogido en un nudo sobre la frente.

32. Francisco Barado, Historia del peinado. Obra utilísima a los pintores, actores y peluqueros de teatro (Barcelona: José Serra Editor, 1880$), 65$. 
Lamentablemente debido a la altura y la presencia de una gruesa capa de polvo, no fue posible observar con mayor detalle las policromías y motivos presentes en las prendas.

En cuanto a las policromías presentes en la indumentaria de ambas esculturas, imitan textiles ricos con diseños vegetales, distinguiéndose además que las prendas como los mantos y las mangas poseen vista interior o "forro" y exterior. La técnica ornamental muestra la planificación de grandes zonas de oro reservadas o cubiertas con pintura al temple en verde, azul y rojo; detalles realizados a punta de pincel y texturas logradas a partir de esgrafiados, punzonados y juegos de picado de lustre para dar diferentes efectos. ${ }^{33}$ Todos los diseños están adaptados al movimiento de las telas, y aunque carecen de sombreados, logran generar un efecto de profundidad. Debido a la extensión de este artículo, y por el tratamiento similar en el tipo de motivos y técnicas decorativas de las prendas, se tomarán ejemplos de ambas tallas para ilustrar algunas particularidades de los estofados.

Las faldas (Fig. 5). Para las más largas, se representó un textil de color verde oscuro, donde los motivos vegetales fueron delimitados a partir de la aplicación de delgadas pinceladas en tono gris y un punzonado continuo en el borde; para los interiores de las formas vegetales el artífice utilizó hasta tres punzones diferentes: cabeza fina, cabeza con línea horizontal y cabeza cilíndrica que permitió marcar únicamente una pequeña circunferencia. Consuelo Maquívar ya había distinguido con anterioridad el uso de este tipo de cabezales en las esculturas del siglo XVIII. ${ }^{34}$ El borde de las faldas lleva una cenefa reservada en dorado, donde a partir de un fino esgrafiado con formas circulares y líneas verticales y horizontales, da la apariencia de tratarse de un rico galón de oro. Las faldas cortas que llegan a la rodilla de las mártires, son de un rosa pálido en Lucía y rojo en la santa mártir, y sus motivos están formados de la misma manera que en la falda larga, por formas vegetales reservadas y cubiertas de picado de lustre, mientras los fondos se esgrafiaron horizontalmente con el fin de imitar la trama de una tela.

Los mantos. Están fondeados con color azul en el caso de Lucía, y rojo en la santa mártir; nuevamente se aprecia el galón en el borde donde se usaron diferentes punzones: cabeza fina, cabeza circular y cabeza en "s", de la combinación entre estos se generó un patrón con un borde marcado por medio de pequeños toques, seguido por una línea de las marcas en " $s$ " y figuras triangulares complementadas con marcas de punzón en línea horizontal. Los diseńos que los cubren en su totalidad son claramente apreciables en la parte posterior de las tallas, tratándose de un motivo vegetal que consta de una guía que se cierra sobre sí misma culminando en un medallón o flor estilizada, acompañada por hojas y finas líneas doradas realizadas a punta de pincel (Fig. 6); el conjunto de estas composiciones céntricas da la apariencia de un textil cubierto por dichos círculos que se cierran sobre sí mismos. Los motivos muestran un patrón de líneas horizontales en su interior y están destacados a partir de un punzonado con cabeza fina que los delimita, mientras que los fondos se aprecian finamente esgrafiados de forma horizontal. La vista interior de los mantos, rojo para Lucía y encarnado para la mártir, está cubierta por una capa de pigmento donde se dibujaron a punta de pincel diseños vegetales delineados con gris, cuyos fondos van ligeramente esgrafiados.

Las pecheras o corsé. Ambas prendas, reproducidas con gran riqueza, van ajustadas al pecho y ceñidas en la cintura y parte de la cadera. Al contrario del manto y las faldas que poseen gran movimiento, estas

33. Amaro Cavada et al., "Los diseños polícromos," 81.

34. María del Consuelo Maquívar, El imaginero novohispano y su obra. Las esculturas de Tepotzotlán (México: INAH, 1995$), 224$. 


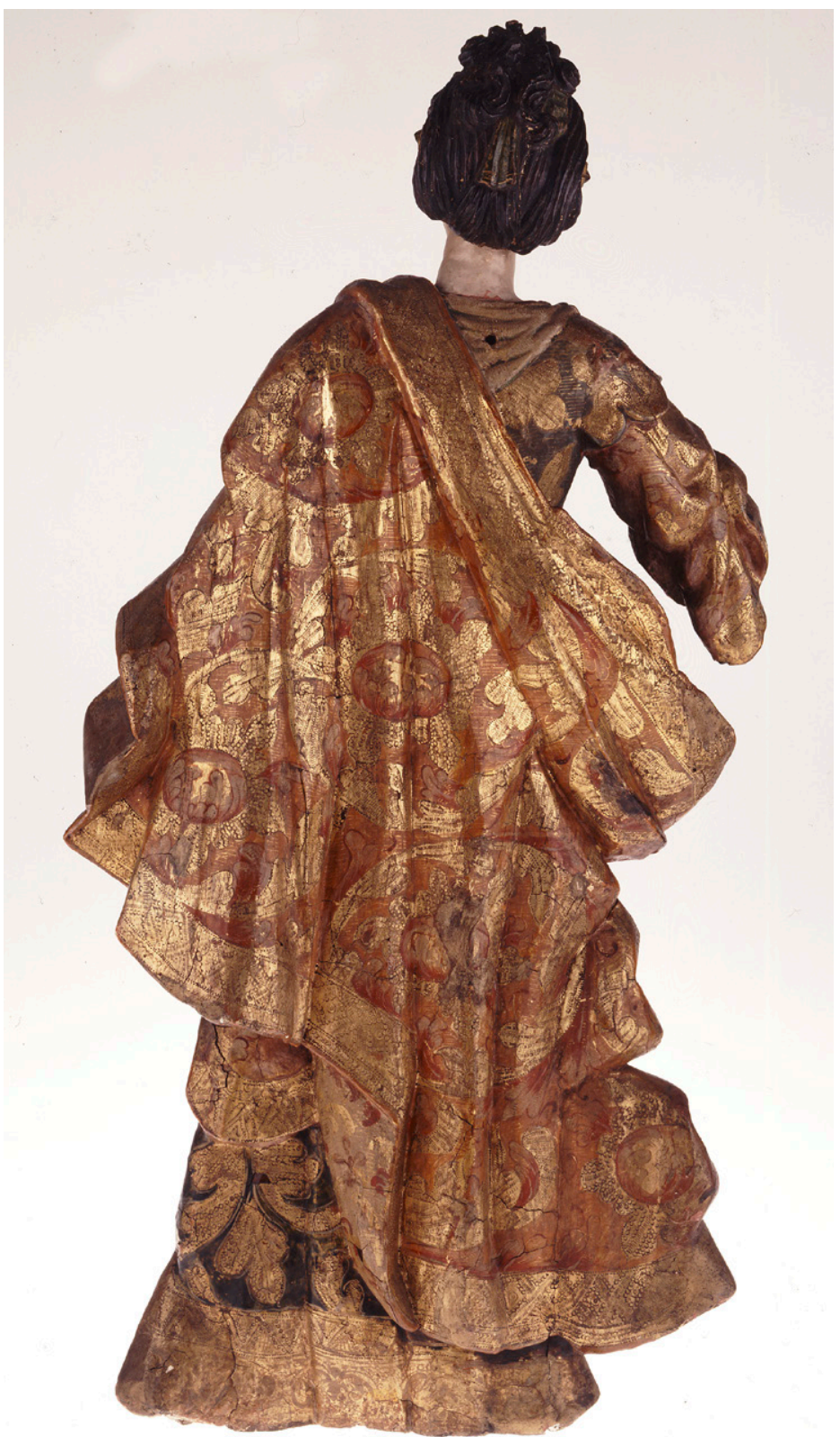

Fig. 6. Autor desconocido, Santa Lucía o santa mártir (detalle del manto), siglo XVIII. Madera tallada, dorada, policromada y estofada. Colección Museo Franz Mayer, Ciudad de México. (Fotografía del Museo Franz Mayer). en una especie de botón del que solo se han abierto los más externos. Las hojas que se advierten en la voluta se ordenan en un mismo sentido, extendiéndose a veces entre los otros círculos para dar movimiento al diseño, cual se diferencia del presente en las mártires, que aparece muy sintetizado y menos geométrico. En los tres casos ya mencionados, el diseño se asienta en la vista posterior del manto, lo que permite apreciar claramente su es-

$\overline{\text { 35. Agradezco a la Dra. Patricia Díaz Cayeros el proporcionarme }}$ dicha noticia. dan la apariencia de ser prendas rígidas ya que no revelan ningún pliegue. Si bien los motivos ornamentales son parecidos a los encontrados en las faldas, no presentan picado de lustre, sino punzonados finos en los bordes y líneas horizontales en el interior, complementado por esgrafiado en los fondos de ambos casos. Cada mártir lleva guarniciones diferentes en esta prenda: Lucía porta en el cuello una especie de collar adornado con cinco piedras preciosas, terminado en dos dijes en forma de flor que le cuelgan del pecho y del que se sostiene un fino paño que le envuelve la cintura. Este paño también forma un moño en el pecho, el textil es de fondo blanco con líneas rojas y verdes. La santa mártir porta también una guarnición en el cuello, y paños que sostenidos por un par de broches, uno de ellos cubierto por el manto, cruzan sobre su pecho para unirse en un tercer broche, de donde también se sostiene una tela que le envuelve la cintura.

Por último sería pertinente destacar el motivo ornamental principal presente en la indumentaria de las santas: una guía vegetal que se cierra sobre sí misma en forma circular y que concluye en un medallón o flor estilizada. Un hallazgo con respecto a este motivo, es que se ha podido ubicar en otros ejemplos escultóricos, siendo el más destacado la Inmaculada Concepción de Ozumba de Alzate, Estado de México. ${ }^{35}$ En el manto de la Inmaculada se aprecia una voluta que cierra su centro en una flor pintada con los pétalos ligeramente abiertos, o
s. Las hojas que se advierten en la voluta se

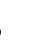

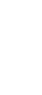

.


tructura. En la ficha catalográfica existe un comentario de Carla Aymes del 17 de junio de 2013 que recomienda ver la capilla de Novicios de Tepotzotlán, a partir del seminario con Héctor Schenone, ${ }^{36}$ y revisando algunas de las esculturas presentes en el recinto, se aprecia que de hecho en el manto de san Juan Bautista y la túnica y manto de san Juan Evangelista, se encuentra un motivo muy similar a la guía concéntrica cerrada en una flor. Únicamente la búsqueda de referentes documentados podrá dar mayores luces acerca de este diseño, que por su configuración se propone que podría ser datable en la primera mitad del siglo XVIII, y para dilucidar si podría formar parte de un modelo ornamental vigente en la Ciudad de México, como ya lo ha estudiado el Seminario de Escultura Virreinal en el caso de las clavellinas ${ }^{37}$ y un diseño ornamental en Chimalhuacán-Chalco y Ozumba. ${ }^{38}$

\section{Santa Lucía: una iconografía inusual} Uno de los aspectos más interesantes de este par de esculturas nos remite a la iconografía de la santa identificada como Lucía, en la cual se centrará este apartado (Fig. 7). La segunda escultura, por carecer de atributos, podría tratarse de cualquier santa mártir de los primeros siglos: Catalina, Bárbara o Águeda; sin embargo al no

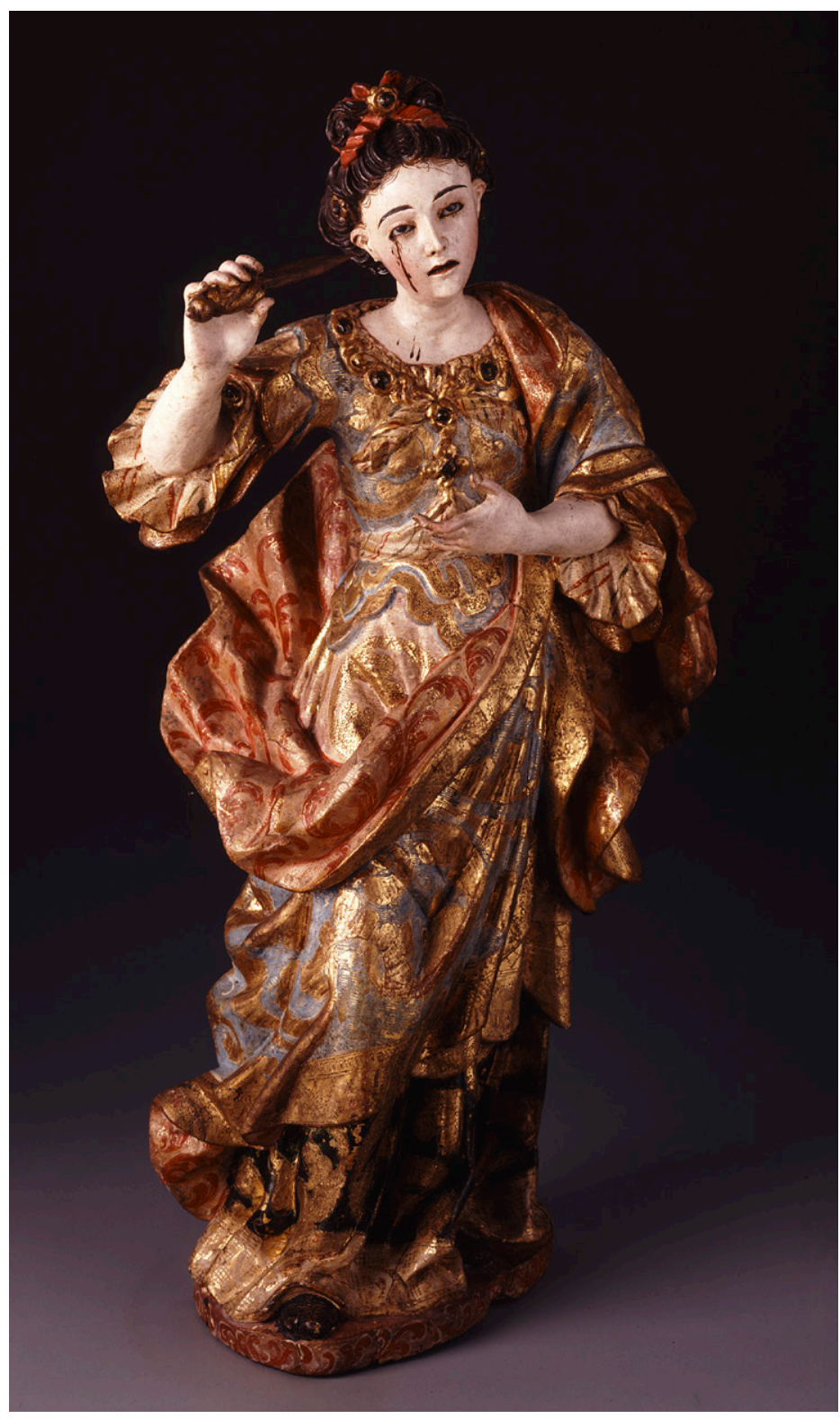

Fig. 7. Autor desconocido, Santa Lucía, siglo XVIII. Madera tallada, dorada, policromada y estofada. Colección Museo Franz Mayer, Ciudad de México. (Fotografía del Museo Franz Mayer). poseer ningún elemento que nos proporcione una pista, la atribución queda abierta a futuras reflexiones. En el caso de santa Lucía, Elisa Vargaslugo es la primera autora en registrar la pieza con este nombre por "estar en el momento de sacarse los ojos" ${ }^{39}$ En las subsecuentes publicaciones Consuelo Maquívar también continúa reconociéndola como tal:

36. Ficha catalográfica. Santa Lucía. Museo Franz Mayer. Fecha de consulta, enero 2019.

37. Amador Marrero et al., "Las clavellinas como una de las posibles," 35.

38. Guillermo Arce Valdez, "Un diseño ornamental en el estofado de algunas esculturas en Chimalhuacán-Chalco y Ozumba," en Amador Marrero y Díaz Cayeros, El tejido polícromo, 93

39. Vargaslugo, "Escultura," 125. 
Según la tradición, [Lucía] fue acusada de practicar el cristianismo en la época del emperador Diocleciano, y para obligarla a renegar de sus creencias le aplicaron varios tormentos; como no lograron que se arrepintiera, ella se sacó los ojos para que entendieran sus verdugos que prefería la muerte a renunciar a su fe. ${ }^{40}$

La autora únicamente apela a la tradición popular en torno a la santa, sin consignar otra fuente. En la sección de "observaciones" de la ficha catalográfica existe una nota ańadida en septiembre del 2005 por Natalia Ferreiro, ${ }^{41}$ donde citando a Louis Réau, comenta que el nombre de Lucía evoca a una idea de luz, llevando por atributo un par de ojos que según una versión "novelesca" ella misma se arrancó para apartarse de un pretendiente pagano. ${ }^{42}$ Por lo tanto, basándose únicamente en el gesto de arrancarse los ojos con el cuchillo, la pieza ha sido nombrada por las autoras como Lucía de Siracusa, una mártir de los primeros tiempos del cristianismo, ya que no posee otros atributos que la distingan. La leyenda de la mártir inmolando sus ojos es uno de sus rasgos más populares y quizá el más arraigado en el imaginario en torno a su vida. Sin embargo, revisando la literatura martirológica relativa a ella, es notorio el silencio acerca de tal hecho.

El Martirologio romano la consigna el 13 de diciembre y destaca que se trataba de una doncella noble y cristiana que, habiéndose negado a casarse con un pagano, fue denunciada por su fe y llevada ante el Prefecto Pascasio, quien ordenó que fuera cruelmente martirizada. Sobre su martirio se explica que "habiéndola atormentado con pez, resina y aceyte hirviendo, como no recibiese daño alguno la atravesaron la garganta con una espada y consumó el martirio", ${ }^{43}$ otras fuentes posteriores como el Flos Sanctorum de Alonso de Villlegas (1534-1615), el Flos Sanctorum de Pedro de Ribadeneyra (1526-1611) y Alban Butler (1709-1773) coinciden en que la mártir murió por decapitación, ${ }^{44}$ mientras que los dos últimos autores denuncian lo incierto infundado de la leyenda de los ojos ya fuera como parte del martirio ${ }^{45}$ o para librarse del pretendiente lascivo que la perseguía. ${ }^{46}$

Dicha denuncia en lo que respecta a la imagen de la santa apareció tras el Concilio de Trento, pues siguiendo la recomendación de la sesión XXV de exterminar imágenes que dieran ocasión a peligrosos errores, ${ }^{47}$ varios tratadistas condenaron la leyenda de los ojos, siendo el primero de ellos el teólogo lovainense Joannes Molano (1533-1585). Al haber sido una de las autoridades encargadas en Trento de la discusión sobre las imágenes sagradas, Molano publicó De picturis et imaginibus sacris o De Historia sacrarum imagi-

40. Maquívar, "Escultura," 272.

41. Ficha catalográfica: Santa Lucía, Museo Franz Mayer. Fecha de consulta, diciembre de 2015.

42. Réau, Iconografía de los santos G-O, 268.

43. Martirologio Romano publicado por orden del Papa Gregorio XIII, y reconocido con la autoridad de Urbano VIII, de Inocencio XI, de Clemente X, y últimamente corregido y aumentado por el Sumo Pontífice Benedicto XIV. Traducido al castellano por D. Agustin Alvarez Pato y Castrillon, con Licencia (Madrid: en la Imprenta Real, 1791), 341

44. Alonso de Villegas, Flos Sanctorum. Vida, y hechos de Jesu-Christo Dios, y Señor Nuestro, y de todos los santos de que reza la Iglesia Catholica. Conforme al Breviario Romano, reformado por Decreto del Santo Concilio Tridentino. Junto con las Vidas de los Santos Proprios de España. Por el M. Alonso de Villegas, Capellan de la Capilla de la Santa Iglesia de Toledo. En esta ultima impresion se han coordenado en uno solo cuerpo por mes, y dia propio de todos los Santos, y algunos otros. Con Licencia (Barcelona: por la Viuda Piferrer, vendese en su libreria, administrada por Juan Sellent, 1787 ), 832.

45. Alban Butler, Vidas de los Padres, Martires y otros principales santos: deducidas de monumentos riginales, y de otras memorias autenticas: ilustradas con notas de historiadores y criticos juiciosos y modernos: corregidas, y aumentadas por manuscritos del mismo autor. Escribíalas en el ldioma Inglés el célbre Rev. Albano Butler: y las traducía al Castellano el Lic. D. Joseph Alonso Ortiz. Tomo XII (Valladolid: En casa de la Viuda, é Hijos de Santander, 1791), 286.

46. Pedro de Ribadeneyra, Flos sanctorum de las vidas de los santos, escrito por el Padre Pedro de Ribadeneyra de la Compañía de Jesus, natural de Toledo. Aumentado de muchas por los PP. Juan Eusebio Nieremberg, y Francisco Garcia, de la misma Compañía de Jesus. Añadido nuevamente las correspondientes para todos los dias del año, vacantes a las antecendentes impressiones, por el muy reverendo Padre Andres Lopez Guerrero, de la Orden de Nuestra Señora del Carmen, de la Observancia, de la Provincia de Castilla. Y en esta ultimamente addicionado con las vidas de algunos santos antiguos y modernos, para satisfacer a las piadosas ansias, y vivos deseos de tantos, como las piden y solicitan. Dividido en tres Tomos, y cada uno destos en quatro meses del año. Tomo Tercero. Contiene las vidas de los santos incluidos en los meses de Setiembre, Octubre, Noviembre y Deziembre. Dedicado a la Magestad Soberana de Christo, Rey, Señor y Redemptor Nuestro. Con Licencia (Barcelona: En la Imprenta de Juan de Piferrer, 1734), 476.

47. El Sacrosanto y Ecuménico Concilio, 359. 
num et picturarum (1570), un volumen sobre la correcta representación de los personajes e historias de la fe, entre ellos la santa siracusana, de quien comenta que su asociación con la salud ocular, estaba sustentada únicamente en la piedad popular y la "vieja mitología". ${ }^{8}$ A continuación cita al teólogo jesuita Théophile Raynaud (1583-1663) quien afirma lo incierto de dicha leyenda al afirmar que los pintores suelen caer en el error de pintar a santa Lucía con los ojos arrancados y exhibidos en un plato, pues la antigua historia del pretendiente que recibe sus ojos para rechazarlo en realidad podría referirse a que Lucía cerró sus ventanas al mundo. ${ }^{49}$ Posteriormente, Francisco Pacheco (1564-16644) en su Arte de la pintura, comenta que aunque queda pendiente en su obra hablar de Lucía, definitivamente "no se los sacò [los ojos] i embiò en un plato". ${ }^{50}$ Por último, Juan Interián de Ayala (1656-1730) proporciona una interesante pista acerca de la iconografía de los ojos:

Esto sea evidentemente falso, y en realidad erroneo y no conforme, ó contra la verdad de la historia, es facil de demostrar. Lo primero, por el profundo silencio que hay sobre esto en sus actas, y escritos (...) los quales todos, no hacen ni la mas ligera mencion de un hecho tan admirable (...) Y ya que tratamos de Imágenes, opongamos á las falsas otras Pinturas verdaderas, y racionales. En el Convento de Madrid, que llaman de la Pasion, que sirve de hospedage á los Padres Dominicos, he contemplado repetidas veces la Imagen de una Santa Monja de dicha Orden, teniendo en un pequeño plato los ojos que ella misma se sacó (...) que por una crasa ignorancia de los hechos, se atribuye á Santa Lucia Martir. ${ }^{51}$

El autor continúa y explica que la casta virgen dominica llamada Lucía, al ser solicitada por un varón noble quien dijo que amaba sus ojos, se los arrancó y envió al pretendiente, quien arrepentido despreció el mundo e ingresó a la Orden de Predicadores de Santo Domingo; con lo que aclara que fue aquella virgen dominica del siglo XV quien realizó dicha acción, y no la mártir siracusana. Acerca de la beata Lucía "la casta”, venerada el día 3 de diciembre en el santoral dominicano, el Sacro diario dominicano de Francisco Vidal, dice: "es venerada por Abogada contra el mal de los ojos, como Santa Lucia Martir, a quien muchos aplican el sobredicho caso: pero todas sus Actas lo callan". ${ }^{52}$ En efecto, existen en Nueva Espańa algunas obras que representan a la dominica donde está vestida con el hábito de la orden y sosteniendo el plato con sus ojos: un lienzo en el convento de Santo Domingo de la Ciudad de México, identificada además por su nombre en la cartela (Fig. 8), y una pintura al fresco en el convento de Santo Domingo de Oaxaca, México. Otros ejemplos se encuentran en el convento de Santo Domingo de Scala Celi en Córdoba, España, y en el Museu de Aveiro, Portugal, antiguo convento de Jesús de monjas dominicas, en cuya iglesia se encuentra un lienzo con la beata Lucía sosteniendo sus ojos en un plato y arrodillada ante Cristo.

De este modo, queda clara la asociación entre santa Lucía de Siracusa y la iconografía ocular, la cual apareció a partir de la etimología popular de su nombre (Lucía, Lux, Lucia a luce), ,53 ya que ni las actas ni

\footnotetext{
48. Johannes Molanus, De historia SS. imaginum et picturarum, pro vero earum usu contra abusus, libri quator; auctore Joanne Molano, regio theologo, et cive lovaniensi. Ejusdem oratio de Agnis Dei, et alia quaedam. Joannes Natalis Paquot, Recensuit, Illustravit, Suppplevit (Lovanii: Typis academicis, 1771 ), 395.

49. Théophile Raynaud, Hagiologium lugduvinense. Videlicet. Tomus octuavuus. Pars hactenus inedita, pars altera tanto fere auctior, cum indice copiosissimo (Ludguni: Sumpt. Horatii Boissat, \& Georgii Remeus, 1650), 514-15.

50. Francisco Pacheco, Arte de la pintura su antiguedad y grandezas. Descriven los hombres eminentes que ha avido en ella, assi antiguos como modernos, del dibujo y colorido; del pintar al fresco; de las encarnaciones, de polimento, y de mate; del dorado, bruñido, y mate. Y enseña el modo de pintar todas las pinturas sargadas. Por Francisco Pacheco, vezino de Sevilla. Con privilegio (Sevilla: por Simon Faxardo, impressor de libros a la cerrajeria, 1649 ), 592.

51. Interián de Ayala, El pintor christiano, 461.

52. Francisco Vidal, Sacro Diario Dominicano en el qual se contiene una breve insinuacion de las Vidas de los Santos. Beatos y Venerables de la Orden de Predicadores para cada día del Año, con alguna Reflexión y Oración. Traducido del italiano al español, y añadido por el M.R.P.N.Fr, Francisco Vidal, Regente de Estudios y Prior que fue del Real Convento de Predicadores de Valencia, y Vicario General de la Provincia de Aragón. Con licencia (Valencia: por Joseph Thomàs Lucas, Impressor del Ilustr. Sr. Obispo Insquisidor General, 1747), 562.

53. Réau, Iconografía de los santos G-O, 269
} 


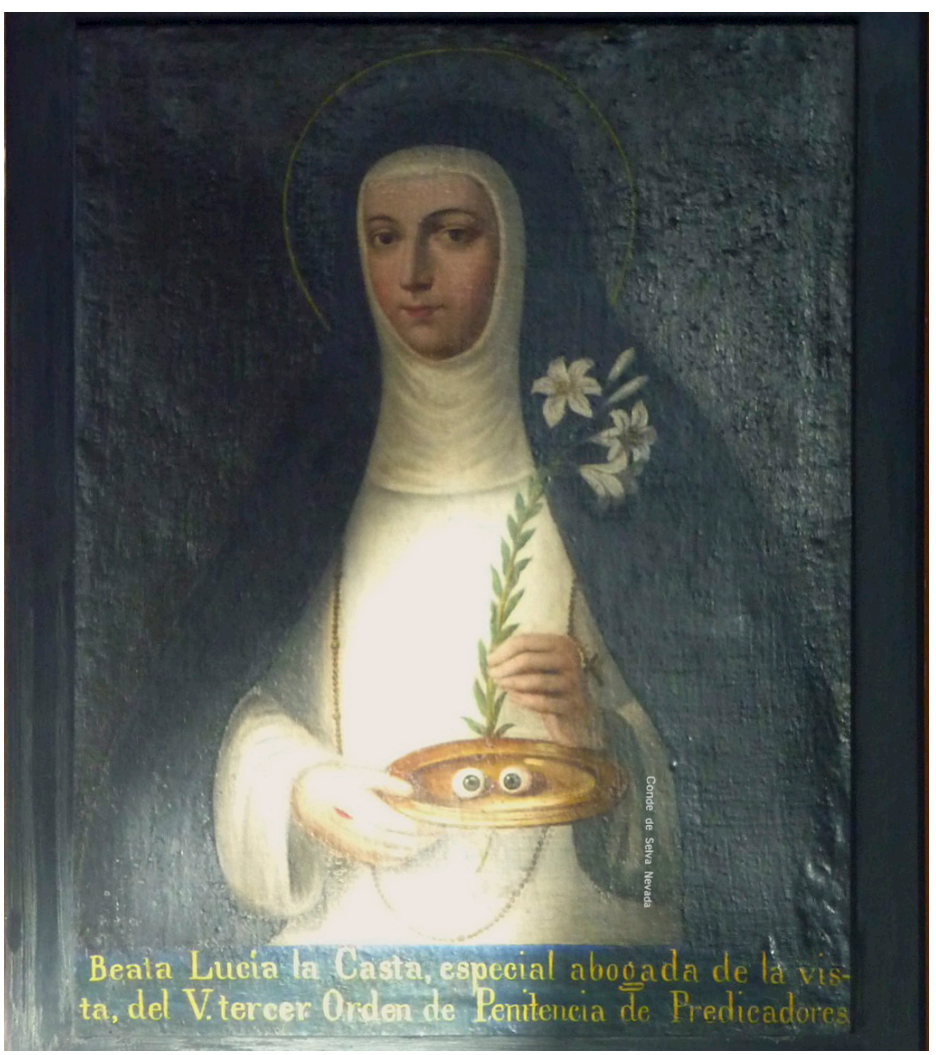

Fig. 8. Autor desconocido, Beata Lucía "la casta", siglo XIX. Óleo sobre tela. Iglesia de Santo Domingo, Ciudad de México. (Fotografía de Alejandro Hernández García). la literatura martirológica incluyen la pretendida narración de los ojos arrancados. Siguiendo la etimología, en algunas de sus representaciones italianas del trecento ya aparece con los ojos al interior de una caja, un plato, o ensartados en una daga: S. Lucia con donante femenina de Jacopo de Casentino (1300-1349) o Santa Lucia en Santa Maria de Magnoli, Florencia, de Pietro Lorenzetti (activo entre 1306 y 1345). A partir de lo ya expuesto, el relato del amante con las santas Lucías parece estar solamente relacionado a nivel popular debido la presencia de los ojos en la iconografía de ambas.

A diferencia de otras mártires de la antigüedad donde los autores aconsejaban pintarlas de un modo en particular o en el momento de su martirio, en el caso de Lucía no quedó claramente establecido. No obstante, sí posee un repertorio iconográfico que se desarrolló a partir de la tradición italiana, país donde nació su leyenda y devoción: su iconografía más usual

la muestra con los ojos en la bandeja o al interior de una caja, un puñal en la garganta o en la mano y una lámpara encendida, ${ }^{54}$ así como las escenas de su vida y martirio. Son ejemplos de obras donde aparece con una lámpara encendida y el puñal en la garganta Santa Lucía de Antonio Vivarini (1449-1450) y Santa Lucía de Filippino Lippi (1457-1504); algunos ciclos de su vida, Vida de santa Lucía de Giovanni di Bartolommeo Cristiani (1367-1398) y Santa Lucia e storie della sua vita de Quirizio da Murano (1462-1478). En el caso de Nueva España, su iconografía se desarrolló principalmente a partir de la circulación de grabados flamencos como S. Lucia de Cornellis Galle (Fig. 9) donde aparece a manera de doncella con un peinado anudado en la coronilla, vestida con manto y túnica, llevando la palma en sus manos y con los ojos sobre un libro. Otras variantes la retrataban durante su martirio, y en un caso excepcional, escenas de su vida, de las que se existe un único ejemplo en la iglesia de San Francisco de Tehuacán, Puebla.

Por lo tanto, la talla de santa Lucía del Museo Franz Mayer destaca no solo por su valor como objeto escultórico, sino también por la gran rareza de su iconografía, ya que — hasta el momento—no se conocen otros ejemplos escultóricos en la Nueva España. ${ }^{55}$ Debido al origen apócrifo del relato de los ojos arrancados, pare-

\footnotetext{
54. Réau, 269.

55. Existe un óleo sobre lienzo del pintor novohispano Juan Rodríguez Juárez (1675-1728) dedicado al mismo tema perteneciente a la catedral de San Luis Potosí, México. Paula Mues Orts, "Santa Lucía," en Pintado en México, 1700-1790: Pinxit Mexici, ed. Ilona Katzew (Los Angeles: Los Angeles County Museum of Art, México: Fomento Cultural Banamex, A.C., y DelMonico Books, 2017), 213-14. Publicado en conjunto con una exhibición del mismo título, organizada y
} 
ce poco probable que esta iconografía, ya condenada por los tratadistas postridentinos, se arraigara en territorio novohispano o se reprodujera numerosamente. La única referencia visual ubicada hasta el momento que se puede relacionar con esta iconografía es un grabado de Zacarías Dolendo (1561-1601), grabador holandés activo en el último tercio del siglo XVI, titulado: Lucia haer selven d'oogen vytsteecken de om vanden Tyran niet verkracht te werden (Fig. 10), la estampa forma parte de una serie de ocho grabados nombrada De geschiedenis van deugdzame vrouwen (La historia de las mujeres virtuosas). El grabado muestra el interior de una habitación donde se aprecia una cama con dosel, un espejo, un par de ventanas y una mesa; en ella se encuentra una mujer joven ricamente vestida; con la mano izquierda sostiene un cuchillo que dirige a las cuencas ya vacías de donde dramáticamente cuelgan sus ojos, mientras un personaje corre a su encuentro con una mano extendida en actitud de sorpresa. En la parte inferior se encuentra una cartela escrita en holandés de la época, cuya traducción aproximada es la siguiente:

Lucía apuñaló sus ojos para que el tirano no la violara: ¿Qué hice para merecer esto que tengo que sufrir?, no puedo soportar-

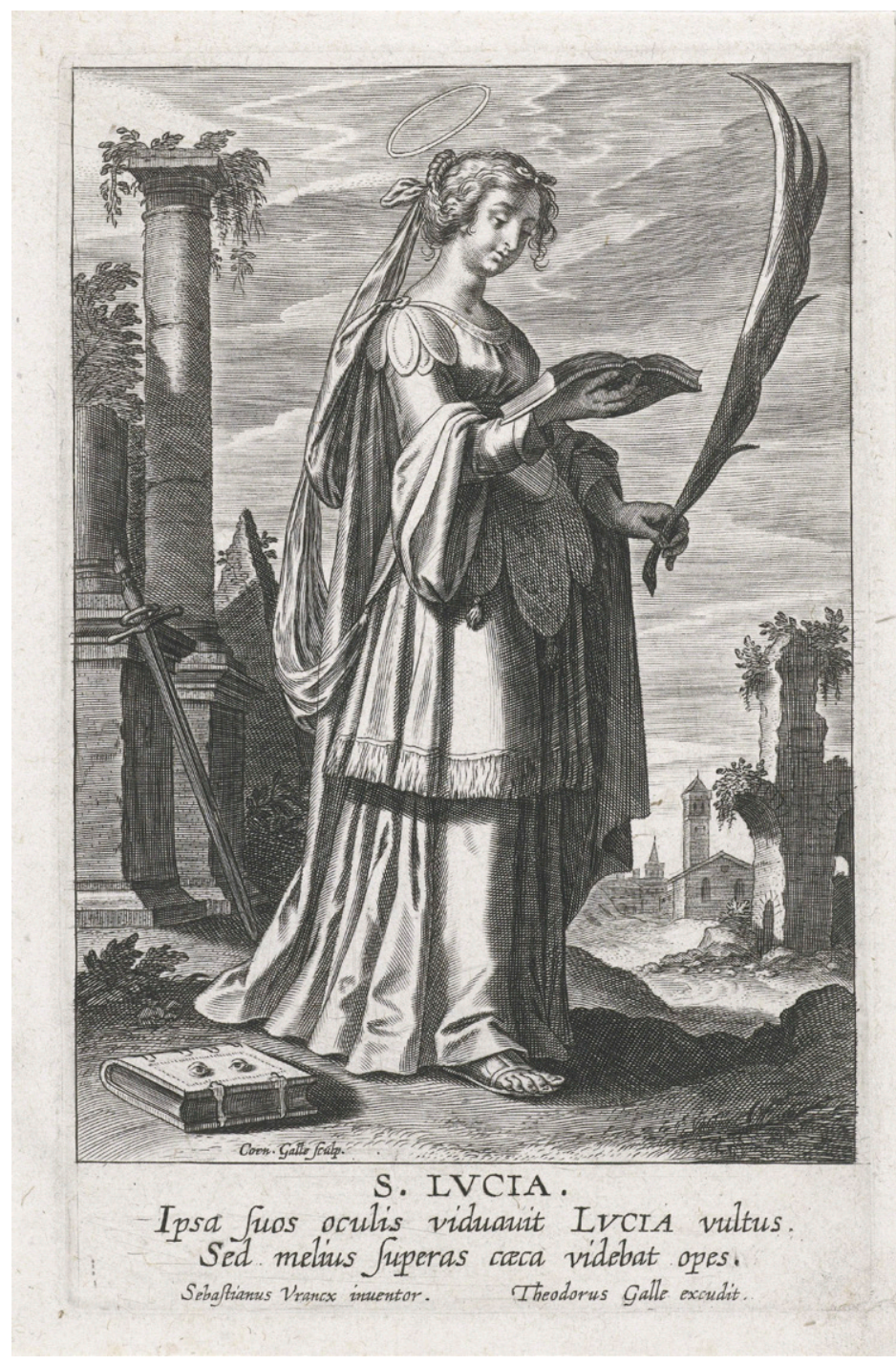

Fig. 9. Cornelis Galle I a partir de Sebastiaan Vrancx, Santa Lucía, 1596-1633. Grabado,150 × 98 mm. Rijksmuseum, Países Bajos. Disponbible en: http://hdl.handle.net/10934/RM0001.COLLECT.114334 lo, el ladrón de mi honor, la causa de mi mal, el enemigo de mi alegría, quien está tras mi pureza. Mis ojos son culpables: los espejos de mi vida. Ellos me advierten, tendré mi venganza de la causa de mi vergüenza, y arrancaré mis dos traidores con mis manos. ${ }^{56}$

La postura de la joven del grabado y la escultura del Franz Mayer guardan similitudes, pues ambas acercan el cuchillo con la mano diestra a sus ojos, y mientras en el grabado ya se ha consumado la acción, en la escultura las gotas de sangre sobre su mejilla y cuello nos advierte del inicio del suplicio. Sin embargo, parece poco probable que esta serie grabada pudiera haber circulado en la Nueva España. ¿Fue la iconografía de esta escultura de santa Lucía la petición especial de un comitente o un despropósito del artífice que la

presentada en Fomento Cultural Banamex, A. C., Ciudad de México, 29 de junio a 15 de octubre de 2017, Los Angeles County Museum of Arte, Los Ángeles, 19 de noviembre de 2017 a 18 de marzo de 2018, y The Metropolitan Museum of Art, New York, 24 de abril a 22 de julio de 2018.

56. Traducción aproximada al inglés por Jonas Derongé. 


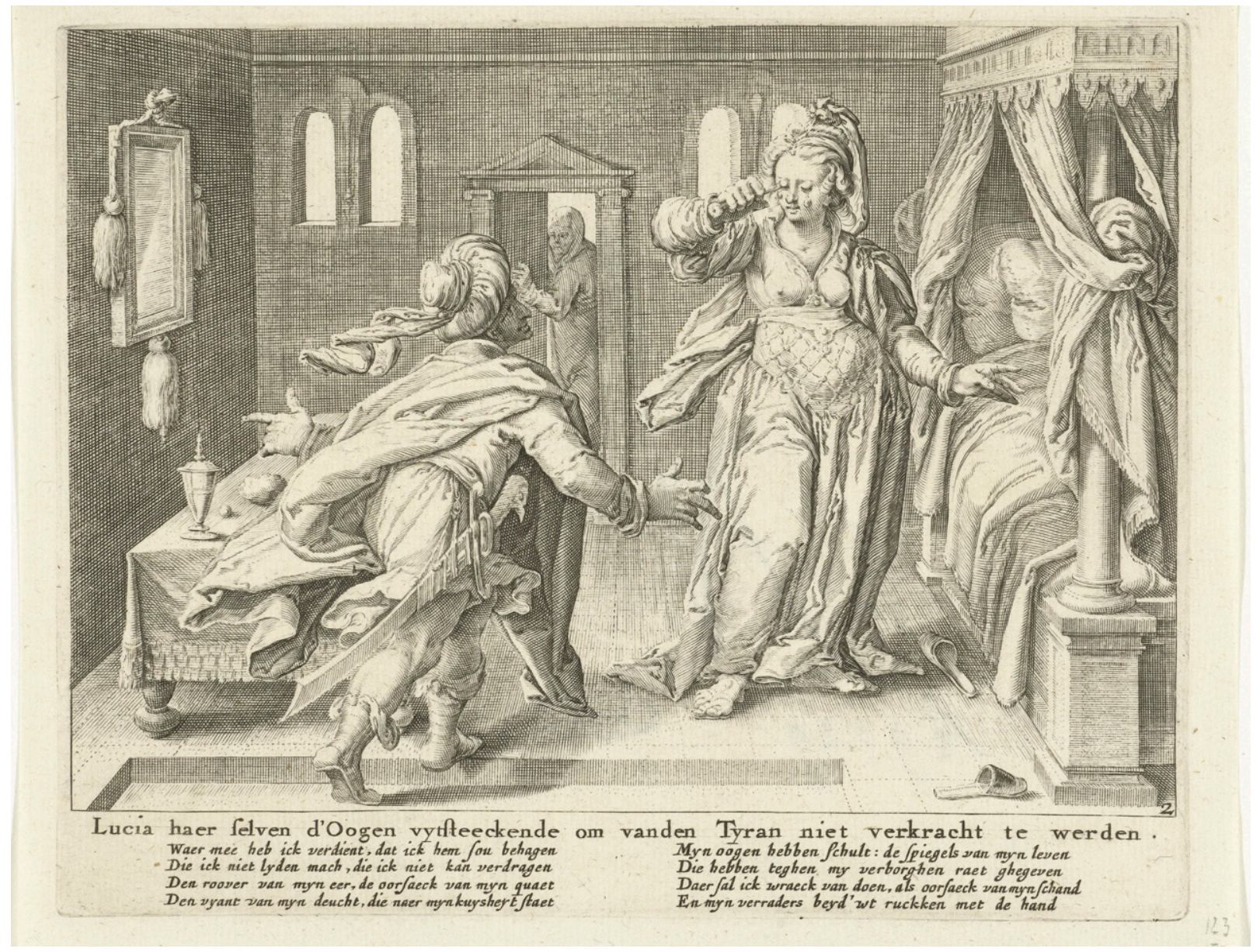

Fig. 10. Zacharias Dolendo a partir de Jacob de Gheyn, Lucia steekt haar ogen uit, Leiden, 1606. Grabado, 142 × 175 mm. Rijksmuseum, Países Bajos. Disponible en: http://hdl.handle.net/10934/RM0001.COLLECT.106133

elaboró? Aunque no es posible dar una respuesta certera a esta cuestión, queda claro que nos encontramos ante un ejemplo único de esta simbiosis iconográfica profundamente arraigada en el imaginario de la vida de la mártir y sus devotos, quizá la única escultura sobreviviente de la censura en territorio novohispano.

\section{Consideraciones finales}

Las tallas identificadas como santa Lucía de Siracusa y una santa mártir son ejemplos destacados de la escultura novohispana del siglo XVIII — como bien han apuntado otras autoras en publicaciones del siglo pasado- pues resaltan por la calidad de la talla y sus estofados al ser dignas representantes de los obradores novohispanos, así como también por la imagen particular que presenta una de ellas. Ambas características permiten reflexionar sobre el proceso de creación de la escultura novohispana y sus diferentes momentos: la selección del motivo o personaje a representar, la planeación y ejecución sobre la materia prima, y por último los procedimientos de ornamentación y acabado. 
Las ricas policromías y estofados que revisten a la santas son en definitiva los protagonistas de ambas esculturas, pues la resolución de los motivos y diseños de los textiles son los que complementan y dan expresión al movimiento de los pańos tallados en la madera. La combinación de la hoja de oro, oculta o revelada por medio de la aplicación de capas de pigmentos al temple que fueron rayados, punzonados o esgrafiados, son todo un despliegue de los recursos del policromador para crear diseños y verosimilitud en la imitación de ricos textiles, llegando en algunos casos a convertirse en diseńos que comienzan a ser tipificados gracias a los nuevos estudios en el campo de la escultura novohispana. De este modo, este artículo propone que el motivo visible en el manto de las mártires que se ha podido ubicar en al menos otras dos obras, y consistente en una guía vegetal que se cierra sobre sí misma en forma circular concluyendo en un medallón o flor estilizada, podría comenzar a rastrearse para dilucidar si puede tratarse o no de un diseño más que contribuya a establecer señas de identidad para la escultura novohispana.

Además de la pericia que requería transformar la madera por medio de las herramientas propias de quehacer escultórico, hay que destacar el trabajo intelectual previo que implicaba para el artífice la búsqueda de un modelo idóneo para resolver la forma de representar al personaje sagrado, pues aunque este era determinado por el comitente, dependía también de su capacidad para elegir el motivo correcto en su calidad de "adornador de Credo Divino, porque las obras que hicieren sean decentes para ser adoradas". ${ }^{57}$ Por ello, el uso del despropósito iconográfico en la representación de la mártir santa Lucía, la convierte en una pieza única en territorio novohispano al haber sobrevivido a la censura. Finalmente, esta obra también permite reflexionar sobre los procesos de desarrollo de la imagen de los personajes sagrados y cómo se modificaban, asimilaban o mezclaban con otros, creando muchas veces leyendas que a pesar de la censura, pervivían en el imaginario de sus devotos.

El primer acercamiento vertido en estas páginas representa un ejercicio de reflexión que pretende sumarse a la problematización del estudio de la historia de la escultura novohispana, dirigiendo nuevamente la atención a este par de esculturas. Aunque las obras se encuentran descontextualizadas y desprovistas de noticias documentales que permitan relacionarlas con espacios específicos o sus comitentes, sí pueden ser estudiadas a partir de sus características formales e iconográficas como destacados ejemplos del trabajo integrado entre los escultores o entalladores y los policromadores novohispanos.

Referencias

Fichas catalográficas

Santa Lucía. BEA0009. Museo Franz Mayer, México.

Santa Lucía. BEA0010. Museo Franz Mayer, México.

\section{Fuentes documentales}

Barado, Francisco. Historia del peinado. Obra utilisima a los pintores, actores y peluqueros de teatro. Barcelona: José Serra Editor, 1880.

57. Maquívar, "El imaginero," 45. 
Butler, Alban. Vidas de los Padres, Martires y otros principales santos: deducidas de monumentos riginales, y de otras memorias autenticas: ilustradas con notas de historiadores y criticos juiciosos y modernos: corregidas, $y$ aumentadas por manuscritos del mismo autor. Escribialas en el Idioma Inglés el célbre Rev. Albano Butler: $y$ las traducía al Castellano el Lic. D. Joseph Alonso Ortiz. Tomo XII. Valladolid: En casa de la Viuda, é Hijos de Santander, 1791.

El Sacrosanto y Ecuménico Concilio de Trento traducido al idioma castellano por Don Ignacio López de Ayala. Agrégase el texto latino corregido según la edición auténtica de Roma, publicada en 1564. Tercera edición. Madrid: Imprenta real, 1787.

Interián de Ayala, Juan de. El pintor christiano, y erudito, ó tratado de los errores que suelen cometerse freqüentemente en pintar, y esculpir las Imágenes Sagradas. Dividido en ocho libros con un apendice. Obra útil para los que se dedican al estudio de la Sagrada Escritura, y de la Historia Eclesiástica, escrita en Latín por el M. R. P. M. Fr. Juan Interian de Ayala, de la Sagrada Real, y Militar Orden de nuestra Señora de las Mercedes, Redencion de Cautivos, Doctor Theólogo de la Universidad de Salamanca, catedrático Jubilado de Theologia, Maestro de Sagradas Lenguas en dicha Universidad, y Predicador de S.M. y traducida en castellano por D. Luis de Durán y de Bastéro, presbitero, Doctor en Theología, y en ambos Derechos, del Gremio, y Claustro de la Pontificia, y Real Universidad de Cervera, Examinador Sinodal del Obispado de Urgél, y Académico de la Real Academia de Cánones, Liturgia, Historia, y Disciplina Eclesiástica de esta Corte. Tomo Segundo. Madrid: por D. Joachin Ibarra, Impresor de Cámara de S.M., 1782.

Martirologio Romano publicado por orden del Papa Gregorio XIII, y reconocido con la autoridad de Urbano VIII, de Inocencio XI, de Clemente X, y últimamente corregido y aumentado por el Sumo Pontifice Benedicto XIV. Traducido al castellano por D. Agustin Alvarez Pato y Castrillon, con Licencia. Madrid: en la Imprenta Real, 1791.

Molanus, Johannes. De historia SS. imaginum et picturarum, pro vero earum usu contra abusus, libri quator; auctore Joanne Molano, regio theologo, et cive lovaniensi. Ejusdem oratio de Agnis Dei, et alia quaedam. Joannes Natalis Paquot, Recensuit, Illustravit, Suppplevit. Lovanii: Typis academicis, 1771.

Pacheco, Francisco. Arte de la pintura su antiguedad y grandezas. Descriven los hombres eminentes que ha avido en ella, assi antiguos como modernos, del dibujo y colorido; del pintar al fresco; de las encarnaciones, de polimento, y de mate; del dorado, bruñido, y mate. Y enseña el modo de pintar todas las pinturas sargadas. Por Francisco Pacheco, vezino de Sevilla. Con privilegio. Sevilla: por Simon Faxardo, impressor de libros a la cerrajeria, 1649.

Raynaud, Théophile. Hagiologium lugduvinense. Videlicet. Tomus octuavuus. Pars hactenus inedita, pars altera tanto fere auctior, cum indice copiosissimo. Ludguni: Sumpt. Horatii Boissat, \& Georgii Remeus, 1650.

Ribadeneyra, Pedro de. Flos sanctorum de las vidas de los santos, escrito por el Padre Pedro de Ribadeneyra de la Compañia de Jesus, natural de Toledo. Aumentado de muchas por los PP. Juan Eusebio Nieremberg, y Francisco Garcia, de la misma Compañia de Jesus. Añadido nuevamente las correspondientes para todos los dias del año, vacantes a las antecendentes impressiones, por el muy reverendo Padre Andres Lopez Guerrero, de la Orden de Nuestra Señora del Carmen, de la Observancia, de la Provincia de Castilla. Y en esta ultimamente addicionado con las vidas de algunos santos antiguos y modernos, para satisfacer a las piadosas ansias, y vivos deseos de tantos, como las piden y solicitan. Dividido en tres Tomos, y cada uno destos en quatro meses del año. Tomo Tercero. Contiene las vidas de los santos incluidos en los meses de Setiembre, Octubre, Noviembre y Deziembre. Dedicado a la Magestad Soberana de Christo, Rey, Señor y Redemptor Nuestro. Con Licencia. Barcelona: En la Imprenta de Juan de Piferrer, 1734. 
Ripa, Cesare. Iconologia overo descrittione di diverse imagini cavate dall'antichità, \& di propia inventione, trovate \& dichiarate da Cesare Ripa Perugino Cavaliere de Santi Mauritio \& Lazaro. Di nuovo revista \& del medesimo ampliata di 400 \& più imagini. Et di figure d' intaglio adornata. Opera non meno utile che necessaria a Poeti, Pittori, Scultori, \& altri, per rappresentare le Virtù, Vitij, Affetti, \& Passioni humane. Roma: apresso Lepido Faeij, 1603.

Vidal, Francisco. Sacro Diario Dominicano en el qual se contiene una breve insinuacion de las Vidas de los Santos. Beatos y Venerables de la Orden de Predicadores para cada dia del Año, con alguna Reflexión y Oración. Traducido del italiano al español, y añadido por el M.R.P.N.Fr, Francisco Vidal, Regente de Estudios, y Prior que fue del Real Convento de Predicadores de Valencia, y Vicario General de la Provincia de Aragón. Con licencia. Valencia: por Joseph Thomàs Lucas, Impressor del Ilustr. Sr. Obispo Insquisidor General, 1747.

Villegas, Alonso de. Flos Sanctorum. Vida, y hechos de Jesu-Christo Dios, y Señor Nuestro, y de todos los santos de que reza la Iglesia Catholica. Conforme al Breviario Romano, reformado por Decreto del Santo Concilio Tridentino. Junto con las Vidas de los Santos Proprios de España. Por el M. Alonso de Villegas, Capellan de la Capilla de la Santa Iglesia de Toledo. En esta ultima impresion se han coordenado en uno solo cuerpo por mes, $y$ dia propio de todos los Santos, y algunos otros. Con Licencia. Barcelona: por la Viuda Piferrer, vendese en su libreria, administrada por Juan Sellent, 1787.

\section{Fuentes bibliográficas}

Amador Marrero, Pablo F., María del Consuelo Maquívar, Montserrat Galí Boadella, Rosa Denise Fallena Montaño, Emma Yanes Rizo, Elva Cristina Sánchez de la Barquera Arroyo, Irma Patricia Díaz Cayeros, y Franziska Martha Neff. Ensayos de escultura virreinal en la Puebla de los Ángeles. México: Fundación Amparo, IIE-UNAM, 2012.

Amaro Cavada, Luis, Mercedes Murguía Meca, y Fanny Unikel Santoncini. "Los diseños polícromos de la indumentaria de las siete esculturas principales en Santa Prisca." En El tejido polícromo. La escultura novohispana y su vestimenta, coordinado por Pablo F. Amador Marrero y Patricia Díaz Cayeros, 77-92. México: IIE-UNAM, 2013.

Arce Valdez, Guillermo, Constanza Ontiveros, y Fanny Unikel Santoncini. "Las clavellinas como una de las posibles señas de identidad de los policromadores de la ciudad de México durante el siglo XVIII.” En El tejido polícromo. La escultura novohispana y su vestimenta, coordinado por Pablo F. Amador Marrero y Patricia Díaz Cayeros, 35-49. México: IIE-UNAM, 2013.

Arce Valdez, Guillermo. "Un diseño ornamental en el estofado de algunas esculturas en ChimalhuacánChalco y Ozumba." En El tejido policromo. La escultura novohispana y su vestimenta, coordinado por Pablo F. Amador Marrero y Patricia Díaz Cayeros, 93-97. México: IIE-UNAM, 2013.

Báez Hernández, Montserrat A. "Del cuerpo violentado al cuerpo glorificado. La imagen del mártir como exemplum maius." En Las funciones de la imagen en el catolicismo novohispano, coordinado por Gisela von Wobeser, Carolina Aguilar García, y Jorge Luis Merlo Solorio, 189-208. México: IIH-UNAM, Fideicomiso Felipe Teixidor y Monserrat Alfau de Teixidor, 2018.

Borromeo, Carlos. Instrucciones de la fábrica y del ajuar eclesiástico. México: UNAM, 2010.

Curiel, Gustavo, coord. Imaginería virreinal: memorias de un seminario. México: IIE-UNAM, INAH, 1990.

Maquívar, María del Consuelo. "Estofados novohispanos del Museo Franz Mayer." Boletín bimestral, no. 25 mayo-junio (1988): 2-4. 
---. Corpus aureum. Escultura religiosa. Colección uso y estilo. Museo Franz Mayer. México: Artes de México, 1995.

---. El imaginero novohispano y su obra. Las esculturas de Tepotzotlán. México: INAH, 1995.

---. "Escultura." En Museo Franz Mayer. 20 años de arte y cultura en México, 249-79. México: Banco de México, 2006.

Mues Orts, Paula. "Santa Lucía." En Pintado en México, 1700-1790: Pinxit Mexici, editado por Ilona Katzew, 213-14. Los Angeles: Los Angeles County Museum of Art, México: Fomento Cultural Banamex, A.C., y DelMonico Books, 2017.

Réau, Louis. Iconografía de los santos G-O. T. 2, vol. 4. Barcelona: Ediciones del Serbal, 2000.

Sánchez Vega, María. "Museo Franz Mayer: origen, historia y actualidad de una institución cultural dedicada a las artes decorativas y el diseño." En Intervención. Revista internacional de Conservación, Restauración y Museología 4, no. 8, julio-diciembre (2013): 54-58.

Vargaslugo, Elisa. “Escultura.” En Franz Mayer. Una colección, 105-41.México: Bancrecer, 1984. 